\title{
PEMANFAATAN DAUN SALAM (Eugenia polyantha) SEBAGAI OBAT HERBAL DAN REMPAH PENYEDAP MAKANAN
}

\author{
Kun Harismah ${ }^{1}$ dan Chusniatun ${ }^{2}$ \\ ${ }^{1}$ Jurusan Teknik Kimia \\ ${ }^{2}$ Jurusan Tarbiyah \\ Universitas Muhammadiyah Surakarta \\ J1. A. Yani Tromol Pos I Pabelan, Kartasura, Surakarta, Indonesia \\ Email: kun.harismah@ums.ac.id
}

\begin{abstract}
Eugenia polyantha, one of Indonesian medicine plant, often used insociety as traditional medicine and also Indonesian culinary additives.Daun salam is called Indonesian bay-leaf, the leaves contain only tiny amounts of an essential oil $0.2 \%$. As main components, eugenol, methylchavicol, and citral have been identified. Thus application to usedof Eugenia polyantha have done. The aim of the present work was the application of Eugenia polyantha for food and health in the community area of Keraton Surakarta. The results indicated that Eugenia polyantha is of particular interest, since it may be an alternative way to carry out of food flavor simultanous as herbal medicine.
\end{abstract}

Keywords: Eugenia polyantha, culinary additive, herbal medicine

\begin{abstract}
ABSTRAK
Tanaman salam (Eugenia polyantha) di Indonesia dikenal sebagai tanaman obat. Tanaman ini juga digunakan oleh masyarakat sebagai obat tradisonal dan penyedap masakan. Daun salam dikenal juga sebagai bay leaf, mengandung sedikit minyak atsiri 0,2\%, mengandung utama senyawa utamametil khavicol, eugenol, dan citral. Kegiatan ini bertujuan pemanfaatan tanaman salam (Eugenia polyanthaWight)untuk kesehatan dan makanan. Sosialisasi dilakukan pada masyarakat di sekitar keraton Surakarta. Hasilnya diperoleh bahwa salam bermanfaat terutama untuk penyedap makanan sekaligus sebagai obat herbal.
\end{abstract}

Kata kunci: Eugenia polyantha, penyedap masakan, obat herbal

\section{PENDAHULUAN \\ Analisis Situasi}

Keraton Surakarta merupakan pusat pemerintahan pada masa sebelum kemerdekaan yang kaya akan adat istiadat, budaya dan ajaran-ajaran luhur. Oleh karena itu perlu ada pemeliharaan dan pemberdayaan agar apa yang masih ada dapat dilihat, dinikmati dan dipelajari oleh generasi mendatang. Dalam hal ini termasuk di dalamnya adalah tanaman yang hingga saat ini belum banyak dimanfaatkan, padahal mempunyai manfaat sangat luas.

Salah satu tanaman tersebut adalah tanaman salam yang telah banyak dikenal oleh masyarakat, biasanya dimanfaatkan sebagai salah satu bumbu dapur atau rempah yaitu penyedap karena memiliki aroma khas 
yang bisa menambah kelezatan masakan. Senyawa-senyawa seperti niasin, serat, tannin, dan vitamin $\mathrm{C}$ yang terkandung dalam daun salam diduga mampu menurunkan kadar trigliserida serum (Soeharto, 2004 dan Moeloek, 2006). Tanaman salam (Eugenia polyantha) merupakan salah satu tanaman yang seringdimanfaatkan masyarakat untuk pengobatan alternatif. Keberadaan tanaman salam yang sudah umum dalam masyarakat dan mudah didapatkan, diharapkan akan mempermudah edukasi dan pengenalan tanaman salam kepada masyarakat sebagai salah satu bahan alternatif sebagai obat herbal untuk kesehatan.

\section{Rumusan Masalah}

Tanaman salam perlu dilestarikan dengan cara sosialisasi pemanfaatannya untuk penyedap makanan,obat herbal,dan budidaya tabaman salam.

\section{Tinjauan Pustaka}

Tanaman salam secara ilmiah mempunyai nama Latin Eugenia polyantha Wight dan memiliki nama ilmiah lain, yaitu Syzygium polyantha Wight. dan Eugenia lucidula Miq. Tanaman ini termasuk suku Myrtaceae. Di beberapa daerah Indonesia, daun salam dikenal sebagai salam (Jawa, Madura, Sunda); gowok (Sunda); kastolam (kangean, Sumenep); manting (Jawa), dan meselengan (Sumatera). Nama yang sering digunakan dari daun salam, di antaranya ubar serai, (Malaysia); Indonesian bay leaf, Indonesian laurel, Indian bay leaf (Inggris); Salamblatt (Jerman) (Dalimartha, 2005; Utami dan Puspaningtyas, 2013). Berdasarkan falsafah Jawa tanaman salam yang ditanam mempunyai makna yang tersirat, yang dapat diambil filosofinya oleh masyarakat untuk diterapkan dalam kehidupan, pohon salam bermakna keselamatan. Tujuan hidup manusia adalah untuk mendapatkan keselamatan di dunia dan di alam akherat nanti.

Daun salam mengandung zat bahan warna, zat samak dan minyak atsiri yang bersifat antibakteri. Zat tanin yang terkandung bersifat menciutkan (astringent). Manfaat daunsecara tradisional, daun salam digunakan sebagai obat sakit perut. Daun salam juga dapat digunakan untuk menghentikan buang air besar yang berlebihan. Pohon salam bisa juga dimanfaatkan untuk mengatasi asam urat, stroke, kolesterol tinggi, melancarkan peredaran darah, radang lambung, gatalgatal, dan kencing manis (KloppenburgVersteegh, 1983). Gambar 1 menunjukkan daun salam.

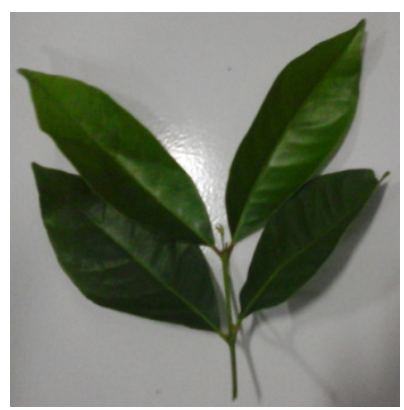

Gambar 1. Daun Salam

\section{Tujuan dan Manfaat.}

Tujuan kegiatan adalah sosialisasi pemanfaatan tanaman salam danbudidayanya. Manfaaat kegiatan adalah masyarakat dapat memanfaatkan tanaman sebagai tanaman rempah penyedap masakan, obat herbal, dan tanaman penghijauan.

\section{METODE PELAKSANAAN}

Pengabdian masyarakat ini dilaksanakan di sekitar Keraton Surakarta, dalam bentuk sosialisasi pemanfaatan tanaman salam dan pelatihan budidaya tanaman salam. Sasaran kegiatan adalah masyarakat yang berdomisili di sekitar Keraton Surakarta yang mempunyai kepedulian dengan pihak Keraton. Lapisan masyarakat ini sangat potensial untuk menjadi penggerak dalam pelestarian tanaman keraton terutama salam.

\section{HASIL KEGIATAN}

Fasilitas tempat untuk sosialisasi kegiatan disediakan oleh keraton Surakarta. Gusti Puger sebagai pihak keraton sangat mudah untuk melakukan koordinasi dengan beberapa abdi dalem dan masyarakat yang akan merawat tanaman. Waktu yang 
disediakan untuk melakukan kegiatan tidak mengganggu kegiatan belajar mengajar tim pengabdian, karena bisa dilakukan pada saat sore hari. Waktu tersebut juga tersedia bagi masyarakat karena mereka sudah tidak melakukan pekerjaan tetapnya.

Untuk tim pengabdian kegiatan ini termasuk kegiatan yang biasa karena tim pengabdian juga tergabung pada penggiat Pusat Studi Lingkungan, sehingga bisa melaksanakan program kegiatan pusat studi berupa pemanfaatan tanaman salam dan perawatannya di keraton Surakarta. Beberapa hal yang disampaikan tentang tanaman salam yang diberikan pada kegiatan ini meliputi kandungan kimia daun salam, sifat kimiawi dan efek farmakologis, manfaat daun salam untuk kesehatan,manfaat daun salam untuk penyedap masakan, dan budidayanya.

\section{Kandungan Kimia Daun Salam}

Tanaman salam mempunyai kandungan kimia minyak atsiri 0,2\% (sitral, eugenol), flavonoid (katekin dan rutin), tannin dan metil kavicol (methyl chavicol) yang dikenal juga sebagai estragole atau p-allylanisole (Gambar 2 dan Gambar 3).

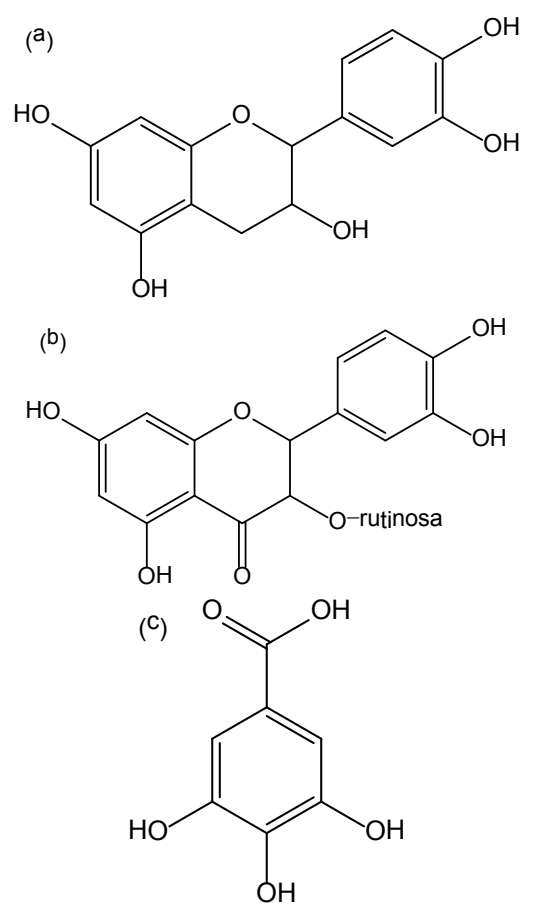

Gambar 2. Senyawa Katekin (a), Rutin (b), Asam Galat (c)
Senyawa tersebut mempunyai aktivitas sebagai antioksidan. Tanin dan flavonoidmerupakan bahan aktif yang mempunyai efek anti inflamasi dan antimikroba (Adjirni, 1999; Katzer, 2001; Sumono dan Wulan, 2009; Lelono, dkk, 2013). Minyak atsiri secara umum mempunyai efek sebagai antimikroba, analgesik, dan meningkatkan kemampuan fagosit. Minyak atsiri daun salam terdiri dari fenol sederhana, asam fenolat misal asam galat (Gambar 2), seskuiterpenoid, dan lakton. Juga mengandung saponin, lemak, dan karbohidrat. Dari beberapa bukti bahan aktif tanaman salam maka tanaman salam mempunyai efek farmakologis.<smiles>CC(C)=CCC/C(C)=C/C=O</smiles><smiles>C=CCc1ccc(OC)cc1</smiles>

Gambar 3. Senyawa Sitral (c), Eugenol (d), Metil kavikol (e)

Eugenia polyantha mengandung tanin, minyak atsiri, seskuiterpen, triterpenoid, steroid, sitral, saponin, dan karbohidrat (Moeloek, 2006). Daun salam juga mengandung beberapa vitamin, di antaranya vitamin $\mathrm{C}$, vitamin $\mathrm{A}$, vitamin $\mathrm{E}$, thiamin, riboflavin, niacin, vitamin $\mathrm{B} 6$, vitamin B12, dan folat. Beberapa mineral pada daun salam yaitu selenium, kalsium, magnesium, seng, sodium, potassium, besi, dan phospor (asiamaya.com).Untuk mendapatkan minyak atsiri, simplisia salam disuling dengan distilasi air dan uap selama 10 jam (Sembiring dkk, 2003 dan Wartini, 2009). Selanjutnya Wartini (2009), ekstrak flavor daun salam mengandung senyawa utama terdiri dari cis-4-dekenal (27,12\%), oktanal (11,98\%), a-pinen (9,09\%), farnesol (8,84\%), ß-osimen $(7,62 \%)$, dan nonanal $(7,60 \%)$. 
Dengan berbagai kandungan zat yang terdapat pada tanaman salam, diharapkan tanaman ini di samping sebagai penyedap alami pada masakan dapat juga berfungsi menurunkan kadar kolesterol yang tinggi, dengan mekanisme kerja yaitu, merangsang sekresi cairan empedu sehingga kolesterol akan keluar bersama cairan empedu menuju usus, dan merangsang sirkulasi darah sehingga mengurangi terjadinya pengendapan lemak pada pembuluh darah. Selain daun yang dapat dimanfaatkan untuk masakan dan obat herbal, oleh Manganti (2011) dijelaskan bahwa kulit pohon salam berwarna cokelat muda keabu-abuan, biasa digunakan oleh nelayan sebagai pewarna jala ikan atau juga untuk pewarna anyaman bambu. Bunga salam kecil, berwarna putih kecoklatan, tumbuh pada malai di ujung ranting. Buah salam berupa beri, bentuk, karakter, dan warnanya mirip buah jamblang (Eugenia cuminii) tetapi ukurannya lebih kecil sekitar $0,6 \mathrm{~cm}$ dengan panjang $1 \mathrm{~cm}$. Buah salam sangat disukai burung, hingga hal ini dimanfaatkan Dinas Pertamanan DKI Jakarta sebagai elemen taman agar burung pemakan buah mau tinggal menetap di taman tersebut. Buah salam bisa dikonsumsi dan enak dimakan, karena daging buahnya sangat tipis maka tidk pernah dimanfaatkan secara ekonomis. Buah yang sudah tua yang tidak dimakan oleh burung akan berjatuhan di bawah tajuk, biasanya buah ini dikumpulkan dan disemai (Foragri, 2012). Dari uraian tersebut tanaman salam dapat dikatakan sebagai tanaman multi fungsi.

\section{Sifat Kimia dan Efek Farmakologis}

Daun salam mempunyairasa kelat, wangi, dan bersifat astringent. Untuk pengobatan bagian daun yang paling banyak digunakan, bagian tanaman lain yang digunakan sebagai obat adalah akar, buah, dan kulit batang. Pengobatan secara tradisional menggunakan daun salam untuk mengobati kolesterol tinggi, kencing manis, hipertensi, gastritis, dan diare(Unp, 2010).

Mekanisme toksisitas fenol pada mikroorganisme meliputi inhibitor enzim oleh senyawa yang teroksidasi,kemungkinan melalui reaksi dengan grup sufhidril atau melalui interaksi non spesifik dengan protein. Sedangkanmekanisme sekuisterpenoid yang terdapat dalam minyak atsiri dispekulasi terlibat dalam kerusakan membransel kuman oleh senyawa lipofilik (Sudarsono, dkk., 2002).

Flavonoid adalah senyawa polifenol yang sesuai dengan struktur kimianyaterdiri dari flavonol, flavon, flavanon, isoflavon, katekin, antosianidin dan kalkon. Flavonoid bermanfaat sebagaianti viral, anti alergik, anti platelat, anti inflamasi, anti tumor dan anti oksidan sebagai sistem pertahanan tubuh.Flavonoid diketahui telah disintesis oleh tanaman dalam responnya terhadap infeksi mikroba sehingga efektif.

\section{Manfaat Daun Salam untuk Kesehatan}

Tanaman salam dikenal sebagai salah satu tanaman yang sering dimanfaatkan masyarakat untuk pengobatan alternatif. Dari beberapa penelitian yang telah dilakukan oleh Dorlan (2002) Boyer dan Liu (2004), Hardhani (2008), Pidrayanti (2008), dan Muhtadi (2010) dapat ditunjukkan tentang berbagai manfaat dari daun salam.

1. Mengurangi dislipidemia, khususnya hipertrigliseridemia.

Hardhani (2008) pemberian ekstrak daun salam pada tikus putih jantan galur Wistar hiperlipidemia dengan dosis bertingkat yang diperoleh dari daun salamsegar sebesar 0,18 gram, 0,36 gram, dan 0,72 gram setiap hari selama 15 hari,dapat menurunkan kadar trigliserida serum tikus tersebut, dengan penurunan paling besar pada pemberian dosis 0,72 gram daun salamsegar. Adanya penurunan kadar trigliserida setelah pemberian ekstrak daun salam membuktikan bahwa terdapat senyawasenyawa aktif dalam daun salam yang mampu menurunkan kadar trigliserida serum. Hanya dalam kurun waktu yang singkat yaitu selama 15 hari, pada dosis 0,72 gam/hari didapatkan rerata kadar trigliserida yang lebih rendah dari kadar 
trigliserida hewan coba pada awal masa adaptasi (pengambilan darah hari ke-0). Senyawa-senyawa yang diduga mampu menurunkan kadar nitrigliserida tersebut adalah niasin, serat, tannin, dan vitamin C. Mekanisme kerja tannin yaitu bereaksi dengan protein mukosa dan sel epitel usus sehingga menghambat penyerapan lemak (Dorlan, 2002). Berdasarkan hal tersebut maka daun salam berpotensi untuk dipakai sebagai bahan obat untuk menurunkan kadar trigliserida pada manusia.

2. Menurunkan kadar LDL

Pemberian diet ekstrak daun salamperoral pada tikus wistar hiperlipidemia dengan dosis $0,18 \mathrm{~g}$ daun salam segar/hari; 0,36 g daun salam segar/hari; 0,72 g daun salam segar/ hari selama 15 hari dapat menurunkan kadar low density lipoprotein (LDL) kolesterol serum tikus secara bermakna $(\mathrm{p}<0,05)$. Semakin tinggi dosis yang diberikan semakin tinggi penurunan kadar LDL kolesterol serum tikus (Pidrayanti, 2008). Daun salamdapat menurunkan kadar LDL kolesterol serum secara bermakna sesuai dengan peningkatan dosis yang diberikan karenadaun salammengandung senyawa aktif seperti quercetin yang terkandung dalam flavonoid selain sifatnya sebagai antioksidan, dapat menghambat sekresi dari Apo-B100 ke intestinum, sehingga jumlah Apo $\mathrm{B}$ akan mengalami penurunan. Apo-B merupakan pembentuk VLDL dan LDL. Berdasarkan survey yang dilakukan terhadap 40.000 wanita dewasa di Amerika Serikat, didapatkan bahwa wanita yang mengkonsumsi makanan dengan kandungan flavonoid, 35\% di antaranya terbebas dari penyakitpenyakit kardiovaskuler. Kandungan quercetin yang tinggi dalam suatu makanan dapat memodulasi aktivitas dari platelet untuk mencegah timbulnya penyakit kardiovaskuler (Boyer dan Liu, 2004).
3. Potensi menurunkan kadar asam urat. Hasil penelitian Muhtadi, dkk (2010) berdasarkan data uji praklinik antihiperurisemia, ekstrak daun salam dan jinten hitam (Nigella sativa Linn) dan kombinasinya dengan dosis tunggal $200 \mathrm{mg} / \mathrm{kgBB}$ terbukti berpotensi menurunkan kadar asam uratdalam darah mencit putih jantan galur BalbC yang diinduksi potassium oksonat dengan prosentase penurunan kadar asam urat berturut-turut adalah 79,35\%, 61,29\%, dan $72,90 \%$. Sedangkan penurunan oleh allopurinol sebesar 93,55\%. Dari hasil standarisasi ekstrak air daun salam adalah parameter kadar fenolat total dalam ekstrak daun salam sebesar $1,08 \%$ dan total flavonoid mempunyai kadar 0,196\%. Dan hasil esktrak air jinten hitam kadar fenolat total sebesar $0,66 \%$ dan kadar flavonoid total sebesar $0,40 \%$. Senyawa identitas dari ekstrak daun salam adalah fluoretin sedangkan ekstrak jinten hitam adalah luteolin. Perbedaan senyawa aktif tersebutlah yang membedakan potensiasi penurunan kadar asam urat darah mencit putih jantan. Dari hasil yang diperoleh lebih poten senyawa fluoretin dari ekstrak daun salam.

\section{Manfaat Daun Salam untuk Penyedap Masakan}

Daun salam merupakan salah satu daun yang dapat dimanfaatkan sebagai rempah atau bumbu dapur yang berfungsi menjadi pengharum dan penyedap alami aneka masakan. Di Indonesia daun salam bisa dipakai pada masakan jenis berkuah maupun tidak berkuahdan dengan penambahan santan atau tidak bersantan. Cara menggunakan daun salam pada masakan yaitu mencampurkan dua atau tiga helai daun segar atau kering ke dalam masakan misalnya daging, ikan, nasi, tahu, tempe, atau sayur mayur sehingga aroma masakan menjadi lebih harum dan sedap. 
Tabel 1. Masakan dengan Salam

\begin{tabular}{ll}
\hline \multicolumn{2}{c}{ Jenis Masakan } \\
\multicolumn{1}{c}{ Bersantan } & \multicolumn{1}{c}{ Tanpa Santan } \\
\hline Sayur lodeh & Sayur bayam \\
Aneka kari & Sayur asem \\
Opor & Sayur bening daun kelor \\
Gulai & Sup \\
Nasi kuning & Tumis-tumisan \\
Nasi uduk & Semur \\
Bongko & Aneka orek (kering) \\
Botok & Aneka soto \\
Garang asem & Cah \\
\hline
\end{tabular}

Untuk penggunaan daun salam kering efeknya tidak seharum penggunaan daun salam segar karena sebagian minyak atsiri yang terkandung sudah menguap, sehingga apabila menggunakan daun salam kering disarankan menambahkan jumlah daun salamnya untuk mendapatkan aroma harum. Aneka macam masakan yang memanfaatkan daun salam dapat dilihat pada Tabel 1 .

Fitri (2007) melakukan penelitian tentang pengaruh penambahan daun salam dengan beberapa konsentrasi terhadap kualitas mikrobiologis, kualitas organoleptis, dan daya simpan telur asin pada suhu kamar. Perlakuan konsentrasi daun salam yang digunakan terdiri atas empat taraf berdasarkan Pengamatan dilakukan sekali dalam dua minggu sampai minggu keempat. dengan perbandingan serbuk daun salamair sebesar 1:4, 2:4, 3:4 dan kontrol. Hasilnya menunjukkan bahwa konsentrasi daun salam berpengaruh terhadap kadar Total Volatile Bases (TVB) telur asin pada lama penyimpanan yang berbeda pada suhu kamar. Variasi konsentrasi daun salam dapat menurunkan jumlah bakteri Staphylococcus aureus pada telur asin, menurut uji mikrobiologis telur asin sudah tidak layakdikonsumsi pada minggu ke 4.Uji TVB telur asin sudah tidak layak dikonsumsi pada minggu kedua.

Apabila menambahkan pada setiap masakan dengan daun salam, terdapatnya kandungan senyawa alami yang mempunyai aktivitas biologi di dalamnya juga bermanfaat untuk menjaga kesehatan dengan meningkatkan daya tahan tubuh. Sehingga sangat dianjurkan untuk menambahkan daun salam pada setiap masakan.Keberadaan tanaman salam yang sudah umum dalam masyarakat dan mudah didapatkan, diharapkan akan mempermudah edukasi dan pengenalan daun salam kepada masyarakat sebagai salah satu bahan alternatif dalam pengobatan, penyedap masakan, dan penyerapan $\mathrm{CO}_{2}$.

\section{Budidaya Tanaman Salam}

Tanaman salam

tumbuh pada tanah dengan ketinggian $0-1500 \mathrm{~m}$ di atas permukaan laut dengan curah hujan 3.000$4.000 \mathrm{~mm} /$ tahun pada jenis latosol kehitaman. Tanaman tersebut belum dibudidayakan secara besar-besaran, sebagian besar hanya tumbuh begitusaja tanpa pemeliharaan (Sembiring dkk, 2003).

Perbanyakan tanaman salam dapat dilakukan secara generatif dengan biji dan secara vegetatif melalui cangkok atau stek. Sebelum penanaman terlebih dahulu dibuatkan lubang tanam dengan ukuran 60x 60x 60cm (Gambar 3)kemudianpemupukan dilakukan dengan diberi pupuk kandang secukupnya. Biji salam mudah sekali tumbuh tetapi dalam beberapa hari daya tumbuhnya akan langsung menurun. Hal ini bisa diantisipasi dengan cara biji salam langsung disemaikan setelah diambil dari tajuk di bawah pohon. Secara generatif biji salam bisa disemai dalam pot kolektif atau pada bedeng penyemaian. Media yang digunakan kompos atau humus yang dicampur pasir. Setelah tanaman tumbuh, untuk mendapatkan daun lebih banyak, dapat dilakukan dengan penambahan pupuk NPK (Foragri, 2012; Sembiring, 2003). 


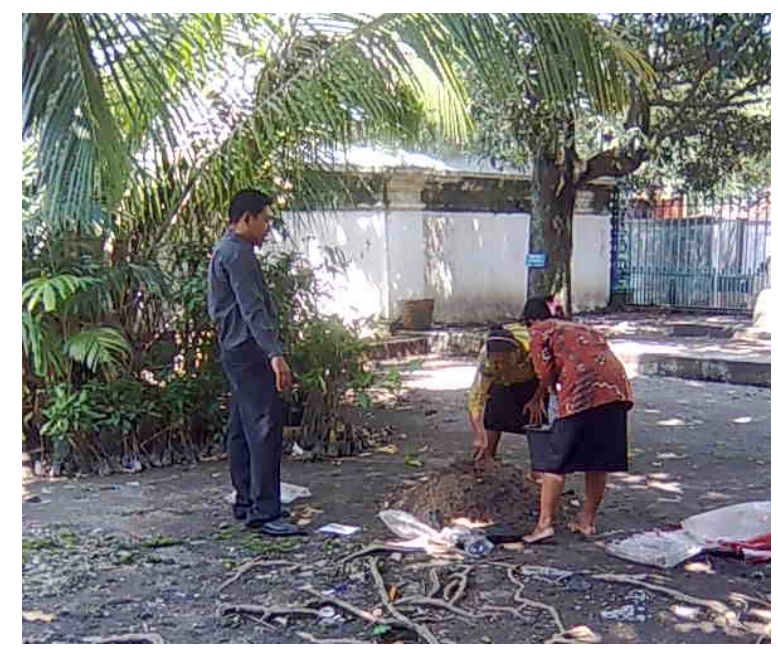

Gambar 3. Pembuatan Lubang Tanam untuk Menanam Salam

Oleh Foragri (2012) diuraikan bahwa semai tanaman salam tumbuh lamban, sampai umur ketinggian tanaman baru mencapai $10 \mathrm{~cm}$. Pertumbuhan tahun kedua dan ketiga akan lebih pesat dibandingkan tahun pertama yang dapat mencapai ketinggian sekitar enam kali yaitu $60 \mathrm{~cm}$. Semaian tersebut baru bisa dipindahkan ke lapangan setelah mencapai ketinggian 1,5- 2,0m atau sekitar 5 tahun sejak biji salam disemai. Apabila pemindahan ke lapangan pada saat ketinggian tanaman di bawah $50 \mathrm{~cm}$ maka akan beresiko tanaman mati pada saat musim kemarau.

Pemanenan salam dilakukan dengan pemetikan daun yang sudah berwarna hijau tua. Daun tersebut dipangkas secara acak pada cabang dan rantingnya. Sesudah daun diperoleh dari rantingnya kemudian daun diseleksi, diikat, kemudian bisa dikirim ke pasar induk dan didistribusikan ke berbagai tempat sampai ke pedagang sayuran untuk diecerkan. Untuk daun yang akan diproses untuk pengambilan minyak atsiri, daun dilayukan dengan cara dihamparkan di lantai pada suhu $\pm 27{ }^{\circ} \mathrm{C}$ (suhu kamar) dengan pembalikan intensif selama kurang lebih tiga hari.

Potensi yang ada pada tanaman salam menjadikan tanaman ini layak untuk dibudidayakan dengan memanfaatkan lahan pekarangan yang kosong. Dengan demikian apabila kita akan memanfaatkannya tanpa harus membeli di pasar. Oleh karena tanaman salam termasuk pohon yang relatif besar dan tinggi hingga bisa mencapai 30 meter dan diameter batang antara 0,6- 1,3 meter (Manganti, 2011) maka tanaman salam juga layak ditanam sebagai tanaman penghijauan. Hal ini terlihat di DKI Jakarta dan sekitarnya tanaman salam digunakan sebagai peneduh jalan dan elemen taman. Di Taman Monas, Ancol, dan Taman Mini Indonesia Indah juga bisa dijumpai tanaman salam (Foragri, 2012). Demikian pula di jalan-jalan kompleks perumahan, tanaman salam sudah dipakai sebagai tanaman peneduh dan di pedesaan sering ditanam sebagai tanaman pagar.Tanaman salam termasuk pohon tahunan kalau berhasil penanamannya akan mendukung program pemerintah kota Surakarta berupa penyusunan rencana tata ruang wilayah, di mana salah satu program yang akan dilaksanakan adalah memperhatikan masalah ruang terbuka hijau.

Berdasarkan uraian di atas, sangat perlu dilestarikan pemanfaatan tanaman salam untuk kesehatan manusia baik untuk pencegahan penyakit maupun perawatan penyakit, serta untukpengelolaan lingkungan. Selain itu dapat ikutmelestarikan salam sebagai salah satu tanaman langka keraton. Dan akan berdampak pula padaterpeliharanya lingkungan ekologi tumbuh-tumbuhan. Pada akhir kegiatan dibagikan bibit tanaman salam kepada masyarakat yang mengikuti kegiatan.

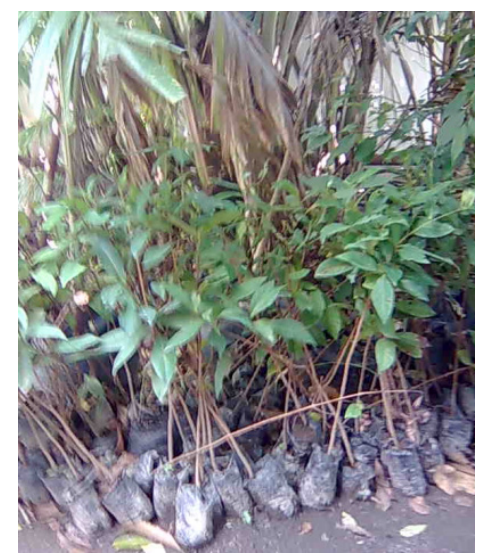

Gambar 4. Bibit Tanaman Salam yang Dibagikan 


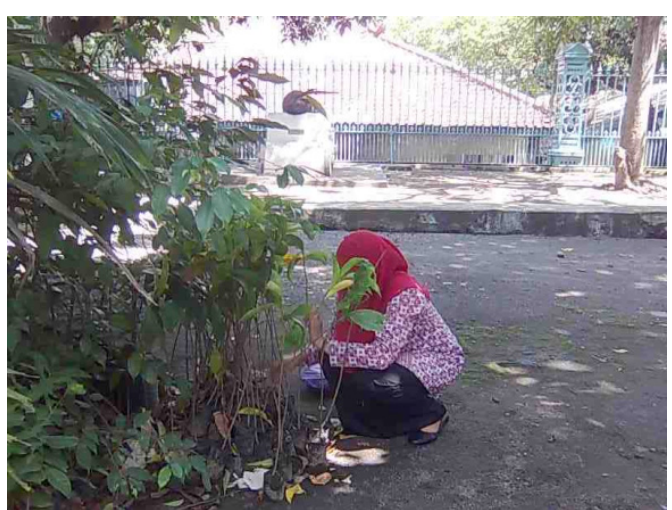

Gambar 5. Menanam Daun Salam

\section{KESIMPULAN}

1. Sosialisasi pemanfaatan tanaman salam sudah dilakukan di sekitar keraton Surakarta.

2. Tanaman salam sebagai penyedap sekaligus juga dimanfaatkan untuk kesehatandan dapat dimanfaatkan sebagai tanaman penghijauan.

\section{PERSANTUNAN}

Penulis megucapkan terima kasih kepada LPPM Univesritas Muhammadiyah Surakarta yang telah membiayai kegiatan ini melalui SK Ketua LPPM Nomor: 03/A.3-III/ LPPM/I/2011.

\section{DAFTAR PUSTAKA}

Adjirni. 1999. Warta Tumbuhan Obat Indonesia. Volume 5, Nomor 3. Jakarta:Kelompok Kerja Nasional Tumbuhan Obat Indonesia.

Jeanelle, Boyer and Hai, Liu Rui. 2004. Apple phytochemical and their health benefits. Nutrition journal. 3:5.

Dalimartha, S. 2005, Tanaman Obat di Lingkungan Sekitar. Jakarta: Puspa Swara.

Dorland WA. Kamus Kedokteran Dorland, $24^{\text {th }}$ ed. Huriawati Hartanto, editor. Jakarta: EGC. 2002.

Fitri, A. 2007. Pengaruh penambahan daun salam (Eugenia polyantha Wight)terhadap kualitas mikrobiologis, kualitas organoleptis dan daya simpan telur asin pada suhu kamar. skripsi. Jurusan Biologi Fakultas Matematika dan Ilmu Pengetahuan Alam Universitas Sebelas Maret Surakarta, Surakarta. core.ac.uk/download/pdf/12347922.pdf. Diakses 24 Nov 2015.

Foragri. 2012. Budidaya Tanaman Salam, http://www.agropustaka.com/2012/04/ budidayatanaman-salam.html. Diakses 16 Desember 2015.

Hardhani, A. S. 2008. Pengaruh Pemberian Ekstrak Daun Salam (Eugenia polyantha) terhadap Kadar Trigliserida Serum Tikus Jantan Galur Wistar Hiperlipidemia. Karya tulis ilmiah, Fakultas Kedokteran Universitas Diponegoro, Semarang.

Katzer, G. 2001. Indonesian Bay-Leaf (Eugenia polyantha Wight.), http://gernot-katzers-spicepages.com/engl/Euge pol.html. diakses 14 November 2015.

Kloppenburg-Versteegh J. 1983. Petunjuk Lengkap Mengenai Tanaman-tanaman di Indonesia dan Khasisatnya sebagai Obat-obatan Tradisional. Yogyakarta: Yayasan Dana Sejahtera.

Lelono, R.A.A. dan Tachibana, S., 2013, Bioassay-guided isolation and identification of antioxidative compounds from the bark of Eugenia polyantha. Pakistan Journal of Biological Sciences, 16(16): 812-818.

Manganti, I. 2011. 40 Resep Ampuh Tanaman Obat Untuk Menurunkan Kolesterol dan 
Mengobati Asam Urat, Yogyakarta: Pinang Merah Publisher.

Moeloek FA. 2006. Herbal and traditional medicine: National perspectivesand policies in Indonesia. Jurnal Bahan Alam Indonesia, 5(1):293-97.

indonesia.digitaljournals.org/index.php/idnmed/.../520.|Diakses 25 Desember 2013.

Muhtadi., Suhendi, A., W, Nurcahyanti., Sutrisna, EM. 2010. Potensi Daun Salam (Syzigiumpolyanthum Walp.) dan Biji Jinten Hitam (Nigella sativa Linn) sebagai Kandidat Obat Herbal Terstandar Asam Urat. http://publikasiilmiah.ums.ac.id/handle/ 123456789/3207. Diakses 29 Desember 2013.

Pidrayanti, L.T.M.U. 2008. Pengaruh Pemberian Ekstrak Daun Salam (Eugenia polyantha) terhadap Kadar LDL Kolesterol Serum Tikus Jantan Galur Wistar. Skripsi. Fakultas Kedokteran, Universitas Diponegoro. Semarang.

Sembiring,B.S., Winarti, C., dan Baringbing, B. 2003. Identifikasi Komponen Kimia Minyak Daun Salam (Eugenia polyantha) dari Sukabumi dan Bogor. Buletin Tanaman Rempah dan Obat 14(2): 9-16.

Soeharto I. 2004. Penyakit jantung koroner dan serangan Jantung, edisi 3. Jakarta: Gramedia Pustaka Utama.

Sumono, A. dan Wulan, S.D.A. 2009. Kemampuan air rebusan daun salam (Eugenia polyantha W.) dalam menurunkan jumlah koloni bakteri Streptococcus sp. Majalah Farmasi Indonesia, 20(3), 112- 117.

Utami, P. dan Puspaningtyas. D.E. 2013. The miracle of herbs. Jakarta: Agro Media Pustaka.

Wartini, N.M. 2009. Senyawa Penyusun Ekstrak Flavor Daun Salam (Eugenia polyantha Wight) Hasil Distilasi Uap Menggunakan Pelarut n-Heksana dan Tanpa n-Heksana. Agrotekno 15(2): $72-77$.

Unp, K., Daun Salam. 2010. http://kimia.unp.ac.id/?p=593, diakses 28 Desember 2013. 